\title{
Quantitative phytochemical analysis and antimicrobial activities of fresh and dry ethanol extracts of Citrus sinensis (L.) Osbeck (sweet Orange) peels
}

\author{
Ehigbai I. Oikeh ${ }^{1,2^{*}}$, Faith E. Oviasogie ${ }^{3}$ and Ehimwenma S. Omoregie ${ }^{1}$
}

\begin{abstract}
Background: Citrus sinensis is one of the most abundant citrus species consumed. Orange peels are a waste byproduct of the fruit and may potentially contain useful phytonutrients with biological relevance.

Methods: Fresh and dry peels of sweet orange were subjected to Soxhlet extraction and then concentrated using a rotary evaporator. Total phenolic, flavonoid and tannin content were determined using standard methods. Antimicrobial activities against five (5) bacterial strains (Staphylococcus aureus, Enterococcus faecalis, Pseudomonas aeruginosa, Escherichia coli and Salmonella typhimurium) and three (3) fungal strains (Candida albicans, Aspergillus niger and Penicillium notatum) was carried out by observing the zone of inhibition using disc diffusion method.

Results: The total phenolic, flavonoid and tannin content was higher in the fresh peel extract compared to the dry peel extract. Antimicrobial activities revealed that the fresh peel extract had better antibacterial activities against all bacterial strains and one fungal strain studied compared to the dry peel extract. Growth of Aspergillus niger and Penicillium notatum were however better inhibited by the dry peel extract than the fresh peel extract.

Conclusion: This study investigated the phenolic content and antimicrobial activities of fresh and dry Citrus sinensis peel extracts. The results from the study conclude that the fresh Citrus sinensis peel extract contains more phenolics and possesses better antimicrobial activities against the studied microbial strains compared to the dry peel extract. The findings in this study suggest that drying plant parts before extraction for phytonutrients may lead to loss of active components.
\end{abstract}

Keywords: Citrus sinensis, Orange peel, Antimicrobial, Bacterial, Fungal, Phytonutrients, Phenolic, Flavonoids

\section{Background}

Citrus sinensis (L.) Osbeck (sweet orange) is the world's most widely grown and commercialized citrus specie. The fruit of C. sinensis is mostly recognized for its vitamin $\mathrm{C}$ content and is also an important source of other phytochemicals such as phenolics and carotenoids which

\footnotetext{
* Correspondence: ehigbai.oikeh@uniben.edu

'Department of Biochemistry, Faculty of Life Sciences, University of Benin,

PMB 1154, Benin City, Nigeria

${ }^{2}$ Department of Chemistry, College of Arts and Sciences, University of

Kentucky, Lexington, USA

Full list of author information is available at the end of the article
}

are reputed to have health benefits [1-3]. The sweet orange fruit is usually eaten whole or processed into juice after the peeling of the external rind (flavedo). This peeling process leads to the generation of substantial wastes [4-7].

Traditional medicine is an established practice in many parts of the world. The use of herbs is well documented and is the oldest approach for healing known [8, 9]. In Nigeria, a huge percentage of the populace depend on herbal medicine for treating different ailments [10]. Studies into the discovery of plant parts with medicinal properties often make use of dried plant parts that are

\section{Springer Open}

() The Author(s). 2020 Open Access This article is licensed under a Creative Commons Attribution 4.0 International License, which permits use, sharing, adaptation, distribution and reproduction in any medium or format, as long as you give appropriate credit to the original author(s) and the source, provide a link to the Creative Commons licence, and indicate if changes were made. The images or other third party material in this article are included in the article's Creative Commons licence, unless indicated otherwise in a credit line to the material. If material is not included in the article's Creative Commons licence and your intended use is not permitted by statutory regulation or exceeds the permitted use, you will need to obtain permission directly from the copyright holder. To view a copy of this licence, visit http://creativecommons.org/licenses/by/4.0/. 
subjected to solvent extraction of bioactive components. This practice often doesn't take into recognition the presence of volatile compounds that may be lost during the drying process.

Microbial drug resistance is a problem of current world interest [11, 12]. The emergence and spread of multidrug-resistance (MDR) microbial strains presents a severe challenge to global public health. Research is increasingly turning towards the use of herbal products as new leads towards the development of better drugs against microbial strains [13].

We have reported in earlier results the presence of phytochemicals as well as evaluated the antioxidant activities of the peels (flavedo), seeds and albedo of dry $C$. sinensis fruits $[1,7]$. Those previous studies evaluated extracts obtained from shade-dried materials. This study therefore compares the phenolic content of fresh and dry C. sinensis peel extracts and evaluates the antibacterial and antifungal activities of these extracts.

\section{Materials and methods \\ Raw materials}

Oranges were purchased from New Benin Market in Benin City, Nigeria. Oranges were obtained same day they were plucked from local farm trees not under any pesticide treatment. The fruits were washed with distilled water and the peels removed with the aid of a sharp knife. Outer peel removal was carried out to ensure that the flavedo was not harvested alongside the albedo. The flavedo were divided into two equal groups. One group was air-dried in a shade at $30-33^{\circ} \mathrm{C}$ for seven days and then pulverized. The other group was pulverized immediately after peeling the oranges and then subjected to extraction. Pulverization was carried out using a sterile mortar and pestle till fine granular or powdery consistency was obtained.

\section{Preparation of plant extract}

The pulverized samples were subjected to Soxhlet extraction for a period of $12 \mathrm{~h}$ with $500 \mathrm{~mL}$ of ethanol and then concentrated using a rotary evaporator at reduced pressure. The extracts were stored in the refrigerator till required for use.

\section{Determination of Total phenolic content}

Total phenolic content was determined according to Folin-Ciocalteau reagent method of Cicco [14]. Concentrations of $0.2,0.4,0.6,0.8$, and $1 \mathrm{mg} / \mathrm{mL}$ of gallic acid were prepared in methanol. Extracts were also prepared in methanol to obtain concentrations of $1 \mathrm{mg} / \mathrm{mL}$. Then $4.5 \mathrm{~mL}$ of distilled water was added to $0.5 \mathrm{~mL}$ of the extract and mixed with $0.5 \mathrm{~mL}$ of a ten-fold diluted FolinCiocalteau reagent. Subsequently, $5 \mathrm{~mL}$ of $7 \%$ sodium carbonate and $2 \mathrm{~mL}$ of distilled water were added. The mixture was allowed to stand for $90 \mathrm{~min}$ at room temperature before the absorbance was read at $760 \mathrm{~nm}$. All determinations were performed in triplicates with gallic acid utilized as the positive control. The total phenolic content was expressed as gallic acid equivalent (GAE).

\section{Determination of Total flavonoid content}

Total flavonoid contents were estimated using the method described by Ebrahimzadeh et al, [15]. Extracts $(0.5 \mathrm{~mL}$ of $1 \mathrm{mg} / \mathrm{mL})$ were mixed with $1.5 \mathrm{~mL}$ of methanol. To this mixture, $0.1 \mathrm{~mL}$ of $10 \%$ aluminium chloride was added, followed by $0.1 \mathrm{~mL}$ of $1 \mathrm{M}$ potassium acetate and $2.8 \mathrm{~mL}$ of distilled water. The mixture was incubated at room temperature for $30 \mathrm{~min}$. The absorbance was measured by a spectrophotometer at $420 \mathrm{~nm}$. The results were expressed as milligrams quercetin equivalents $(\mathrm{QE})$ per gram of extract (mg QE/g extract).

\section{Determination of Total tannin content}

The total tannin content was determined by modified method of Polsheltiwar et al., [16]. To $0.1 \mathrm{~mL}$ of $1 \mathrm{mg} /$ $\mathrm{mL}$ sample extracts was added $0.5 \mathrm{~mL}$ of Folin-Denis reagent followed by $1 \mathrm{~mL}$ of $\mathrm{Na}_{2} \mathrm{CO}_{3}(0.5 \% \mathrm{w} / \mathrm{V})$ solution and distilled water up to $5 \mathrm{~mL}$. The absorbance was measured at $755 \mathrm{~nm}$ within $30 \mathrm{~min}$ of reaction against blank. The total tannin in the extract was expressed as the equivalent to tannin acid.

\section{Antimicrobial assay}

\section{Test microorganisms}

Eight (8) microorganisms were used in this study - Five bacterial strains and three fungal strains. Two were gram positive (Staphylococcus aureus and Enterococcus faecalis) while the other three were gram negative (Pseudomonas aeruginosa, Escherichia coli and Salmonella typhimurium). The three fungal strains used are Candida albicans, Aspergillus niger and Penicillium notatum. All microorganisms were clinical isolates obtained from Lahor Research and Diagnostic Laboratories, Benin City, Nigeria. The identities of the test organisms were confirmed to the specie levels using standard biochemical and morphological procedures.

\section{Antimicrobial susceptibility assay}

Test organisms and 2 control strains (S. aureus ATCC 25923 and E. coli ATCC 25922) were sub-cultured onto fresh suitable broth medium. Broth cultures were then incubated at $37^{\circ} \mathrm{C}$ till the turbidity of $0.5 \mathrm{McF}$ arland's standard $\left(1.5 \times 10^{8} \mathrm{CFU} / \mathrm{mL}\right)$. Mueller-Hinton agar was used as bacterial medium and Sabouraud agar as fungal medium. All were incubated appropriately as specified for each test organism. The turbidity of the actively growing broth culture was adjusted with sterile saline to 
obtain 0.5 McFarland's standard turbidity. One milliliter of the suspension was then used to flood the surface of solid Mueller-Hinton agar plates and drained dry. Wells of $5 \mathrm{~mm}$ in diameter and about $2 \mathrm{~cm}$ apart were punched in the culture media with sterile cork borer. The extracts $(0.2 \mathrm{~mL})$ were thereafter used to fill the boreholes. Each plate was kept in the refrigerator at $4{ }^{\circ} \mathrm{C}$ for $1 \mathrm{~h}$ before incubating at $37^{\circ} \mathrm{C}$ for $24 \mathrm{~h}$ (bacteria) and $72 \mathrm{~h}$ (fungi). Zones of inhibition around the wells, measured in millimeters, were used as positive bioactivity. All experiments were carried out in triplicates.

\section{Minimum inhibitory concentration (MIC)}

The organisms that showed susceptibility to the different solvent extracts were introduced into the broths containing different concentrations of each extract (Serial dilutions of the extracts corresponding to $200 \mu \mathrm{g} / \mathrm{mL}$, $100 \mu \mathrm{g} / \mathrm{mL}, 50 \mu \mathrm{g} / \mathrm{mL}, 25 \mu \mathrm{g} / \mathrm{mL}$ and $12.5 \mu \mathrm{g} / \mathrm{mL})$. The tubes were thereafter incubated for $24 \mathrm{~h}$ at $37^{\circ} \mathrm{C}$. The MIC was taken as the lowest concentration of the extracts that did not permit any visible growth.

\section{Minimum bactericidal concentration (MBC) and minimum fungicidal concentration (MFC)}

The tubes that showed no turbidity in the MIC test were taken and a loop-full from each tube was streaked on Mueller Hinton agar. The plates were incubated for $24 \mathrm{~h}$ at $37^{\circ} \mathrm{C}$ and the absence of growth was observed. The concentration of the extracts that showed no growth was recorded as the MBC / MFC.

\section{Statistical analysis}

The data were expressed as mean \pm SEM of three replicates. The data were subjected to one-way analysis of variance (ANOVA), and differences between means were determined by Duncan's multiple range test using the
Statistical Analysis System (SPSS Statistics 17.0) where applicable. $P$ values $\leq 0.05$ were regarded as significant.

\section{Results}

The fresh peel extract (FPE) was observed to contain significantly higher $(\mathrm{p}<0.05)$ phenolics than the dry peel extract (DPE). Total phenol was 27.14 $\pm 0.23 \mathrm{mg}$ GAE $/ \mathrm{g}$ of extract and $3.64 \pm 0.09 \mathrm{mg} \mathrm{GAE} / \mathrm{g}$ of extract for FPE and DPE, respectively (Fig. 1a). FPE was estimated to contain a flavonoid content of $86.82 \pm 1.82 \mathrm{mg} \mathrm{QE} / \mathrm{g}$ of extract while DPE was estimated to contain $59.94 \pm 0.06$ $\mathrm{mg}$ QE/g of extract (Fig. 1b). Figure 1c shows the estimation of tannic content. Total tannins estimated were $28.50 \pm 6.80 \mathrm{mg} \mathrm{TE} / \mathrm{g}$ of extract for FPE compared to $8.00 \pm 0.33 \mathrm{mg} \mathrm{TE} / \mathrm{g}$ of extract in the DPE.

The results show that both the FPE and DPE of $C$. sinensis possess varying degrees of antimicrobial activities against the test bacterial and fungal strains (Tables 1 and 2). The FPE produced the widest zone of inhibition (ZOI) of $20 \mathrm{~mm}$ against $E$. faecalis. This was followed by $S$. aureus and $P$. aeruginosa with $14 \mathrm{~mm} \mathrm{ZOI} \mathrm{and} E$. coli with $13 \mathrm{~mm}$ ZOI (Table 1). The FPE produced a $6 \mathrm{~mm}$ ZOI for $S$. typhimurium., the lowest observed for the bacterial strains studied. The DPE produced generally smaller zones of inhibition against the bacterial strains with a $12 \mathrm{~mm}$ zone of inhibition observed for $E$. faecalis and $10 \mathrm{~mm}$ for $S$. typhimurium. The DPE produced 4 $\mathrm{mm}, 6 \mathrm{~mm}$ and $8 \mathrm{~mm}$ zones of inhibition, respectively against $S$. aureus, $P$. aeruginosa and E. coli.

Table 2 shows that the FPE was most effective against C. albicans, producing an $18 \mathrm{~mm}$ ZOI while the DPE was most effective against $P$. notatum. with an observed ZOI of $10 \mathrm{~mm}$. Two (2) $\mathrm{mm}$ zones of inhibition were observed for the FPE against $A$. niger and $P$. notatum. while 2 and $4 \mathrm{~mm}$ respectively for $C$. albicans and $A$. niger when exposed to the DPE.

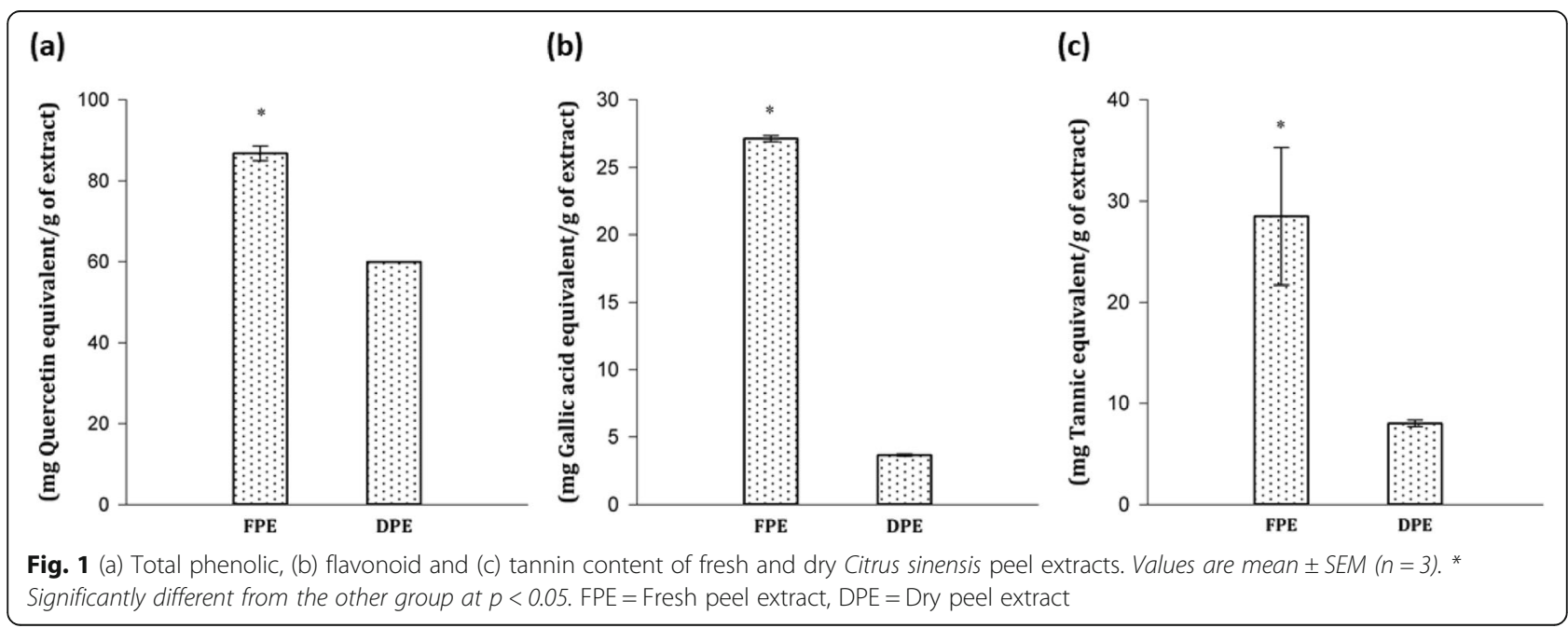


Table 1 Antibacterial activities of Citrus sinensis peel extracts $(200 \mu \mathrm{g} / \mathrm{mL})$ against some bacterial strains tested by disc diffusion assay

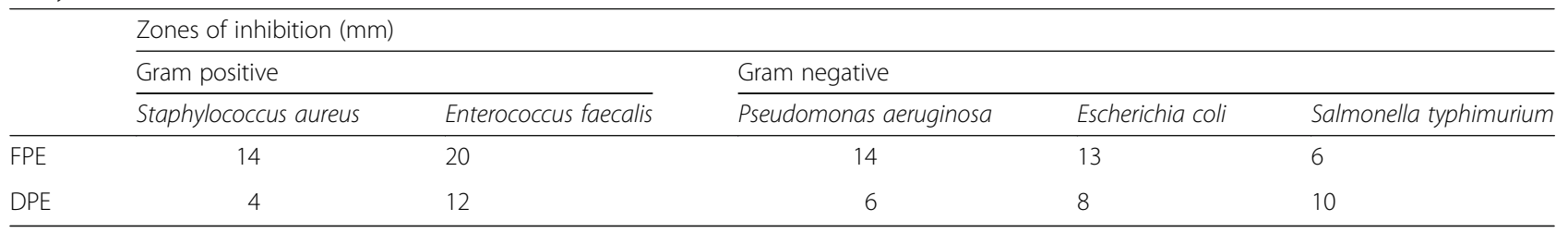

Values are mean of 3 biological replicates to the nearest $\mathrm{mm}$

Table 3 shows that the minimum inhibitory concentrations (MIC) ranged from 12.5 to $100 \mu \mathrm{g} / \mathrm{mL}$. The lowest MIC value $(12.5 \mu \mathrm{g} / \mathrm{mL})$ was observed for the FPE against $S$. aureus, E. faecalis and $P$. aeruginosa. MIC values were higher for the DPE against the same microbial strains. DPE had MIC value of $50 \mu \mathrm{g} / \mathrm{mL}$ against $P$. aeruginosa and $S$. typhimurium. $\mathrm{MBC}$ values were generally higher than the MIC values obtained ranging from $25 \mu \mathrm{g} / \mathrm{mL}$ for the FPE against S. aureus, E. faecalis and $P$. aeruginosa to $200 \mu \mathrm{g} / \mathrm{mL}$ for DPE against $S$. aureus, $E$. faecalis and E. coli.

MIC and MFC against three fungal strains studied are shown in Table 4. The DPE had lower MIC and MFC values against $A$. niger $(50 \mu \mathrm{g} / \mathrm{mL}$ and $100 \mu \mathrm{g} / \mathrm{mL}$ respectively) compared to the FPE $(100 \mu \mathrm{g} / \mathrm{mL}$ and $200 \mu \mathrm{g} /$ $\mathrm{mL}$ for MIC and MFC respectively) Similar MIC and MFC $(100 \mu \mathrm{g} / \mathrm{mL}$ and $200 \mu \mathrm{g} / \mathrm{mL}$ respectively) were observed for both FPE and DPE against P. notatum.

Values are mean of 3 biological replicates to the nearest $m m$.

Values are mean of 3 biological replicates to the nearest $\mathrm{mm}$.

$\mathrm{MIC}=$ Minimum inhibitory concentration; $\mathrm{MBC}=$ Minimum bactericidal concentration.

$\mathrm{MIC}=$ Minimum inhibitory concentration; $\mathrm{MFC}=$ Minimum fungicidal concentration.

\section{Discussion}

The increasing existence of microbial resistance to drugs has made the search for new antimicrobial drugs an important and ongoing one. A current approach is to screen medicinal plants for novel antimicrobial principles. Bioactive natural products from plants have proven

Table 2 Antifungal activities of Citrus sinensis peel extracts $(200 \mu \mathrm{g} / \mathrm{mL})$ against some bacterial strains tested by disc diffusion assay

\begin{tabular}{llll}
\hline \multicolumn{2}{l}{ Zones of inhibition $(\mathrm{mm})$} \\
\hline FPE & Candida albicans & Aspergillus niger & Penicillium notatum \\
DPE & 2 & 2 & 2 \\
\hline
\end{tabular}

Values are mean of 3 biological replicates to the nearest $\mathrm{mm}$ to be very useful in the drug design and discovery process [17].

Secondary metabolites in citrus plants have been identified as therapeutic agents in the management of several diseases. Phytochemical analysis of Citrus sinensis has revealed the presence of carbohydrates, flavonoids, glycosides, coumarin glycosides, volatile oils, organic acids, fats and fixed oils [7, 18]. Tannins, flavonoids, saponins, phenolic compounds and essential oils are believed to be the phytochemicals responsible for the antimicrobial effects of plants [13]. Flavonoids have been linked to several biological activities including antibacterial, antioxidant and inflammatory activities. They are also known to possess the capacity to modulate enzymatic activities and inhibit cell proliferation. In plants, they are known to play a defensive role against invading pathogens $[17,19,20]$. Tannins form complexes with prolinerich proteins that inhibit cell protein synthesis. Synergistic action of tannins, flavonoids, alkaloids and saponins are known to inhibit the growth of pathogens [21].

The results of this study revealed that the fresh $C$. sinensis peel extract had significantly higher total phenol, total flavonoid and total tannin content than the dry peel extract. This may be due to loss of volatile compounds in the fresh peels during the drying process. This finding challenges the widespread practice of drying natural plant parts before solvent extraction of bioactive components from them. The drying process may lead to loss of potent compounds that may contribute to therapeutic/ pharmacological activity of the plant material.

Our results agree with the findings of El-Desoukey et al [22] and Baba et al [23] who also investigated antimicrobial activities of $C$. sinensis peel extracts. Those papers however examined fewer organisms. The present study suggests that the fresh $C$. sinensis peel extract may have potent activity against microorganisms as a result of the high levels of phenolics, flavonoids and tannins present. Synergistic action of these groups of phytochemicals may be responsible for the antimicrobial effects observed in this study. On the other hand, the dry $C$. sinensis peel extract was observed to contain lower total phenolic, flavonoids and tannin content. This may explain why this extract is not as effective as an antimicrobial agent compared to the fresh peel extract. The 
Table 3 Minimum inhibitory and bactericidal concentrations of Citrus sinensis peel extracts against some bacterial strains expressed in $\mu \mathrm{g} / \mathrm{mL}$

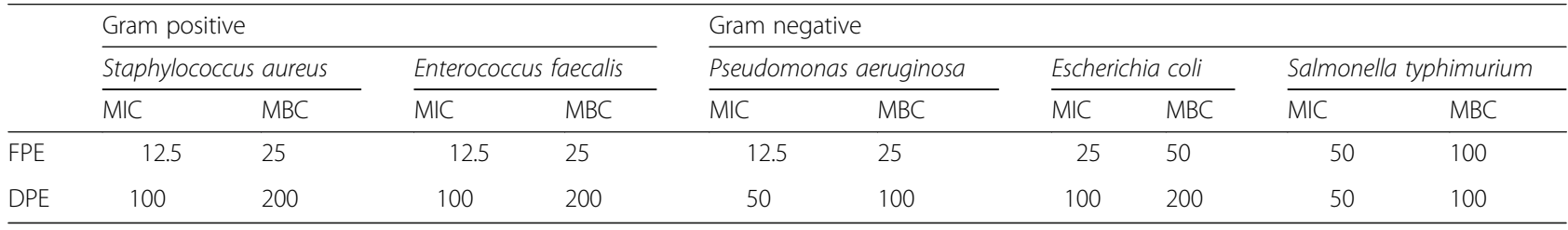

$\mathrm{MIC}=$ Minimum inhibitory concentration; $\mathrm{MBC}=$ Minimum bactericidal concentration

antimicrobial effects observed in the dry peel extract may therefore be ascribed majorly to its flavonoid content.

Aromatic phenolic compounds in plants are well known to possess wide spectra of antimicrobial activity. These compounds are synthesized in plants dealing with a microbial infection. It has been suggested that their activity may be due to their ability to form complexes with extracellular and soluble proteins as well as bacterial cell walls [18]. This may therefore explain further, the better antibacterial effect of the fresh peel extract when compared to the dry peel extract.

Candida spp. are among the most frequently isolated microorganisms in clinical microbiology laboratories. Their relevance hinges on their ability to cause opportunistic and hospital-acquired infections [24]. In this study, the antifungal analysis shows that the fungal strains were not as susceptible to the $C$. sinensis peel extracts compared to the bacterial strains. The fresh peel extract was however effective in inhibiting the growth of C. albicans (ZOI $18 \mathrm{~mm}$ ). The fresh peel extract may therefore hold promise as an antifungal agent for the management of candidiasis.

A surprising result was the greater zones of inhibition against the growth of $A$. niger and $P$. notatum by DPE compared to the FPE. It was expected that the FPE would have better antifungal activity compared to the DPE because of the greater phytochemicals in the FPE. The reason for this observation is not well understood. Further investigation utilizing a more diverse range of fungal organisms may however provide more insight as to whether DPE has better antifungal activities compared to FPE.

Table 4 Minimum inhibitory and fungicidal concentrations of Citrus sinensis peel extracts against some fungal strains expressed in $\mu \mathrm{g} / \mathrm{mL}$

\begin{tabular}{|c|c|c|c|c|c|c|}
\hline & \multicolumn{2}{|c|}{ Candida albicans } & \multicolumn{2}{|c|}{ Aspergillus niger } & \multicolumn{2}{|c|}{ Penicillium notatum } \\
\hline & $\mathrm{MIC}$ & MFC & $\mathrm{MIC}$ & MFC & $\overline{M I C}$ & MFC \\
\hline FPE & 25 & 50 & 100 & 200 & 100 & 200 \\
\hline DPE & 50 & 100 & 50 & 100 & 100 & 200 \\
\hline
\end{tabular}

MIC = Minimum inhibitory concentration; MFC = Minimum fungicidal concentration

\section{Conclusion}

This preliminary study forms the basis for further research into the identification of the antibacterial compounds present in the peels of $C$. sinensis. This further emphasizes the waste-to-wealth potential of sweet orange wastes. The results in this study show that fresh $C$. sinensis peel extract contains more phenolics and possesses better antimicrobial activities against the microorganisms studied compared to the dry peel extract. Our findings also suggest that drying of plant materials prior to extraction may not always be better as certain active pharmacological compounds may be lost during this process.

\section{Acknowledgements}

The authors acknowledge and appreciate the support and resources made available at Lahor Research Laboratory and Medical Centre, Benin-City.

\section{Authors' contributions}

All authors contributed equally. All authors read and approved the final manuscript.

\section{Funding}

Authors declare that they did not receive any fund for this work.

Availability of data and materials

All data pertaining to this study have been included in this article.

\section{Ethics approval}

Not applicable.

\section{Consent for publication}

Not applicable.

\section{Competing interests}

All authors declare that they have no competing interests.

\section{Author details}

'Department of Biochemistry, Faculty of Life Sciences, University of Benin, PMB 1154, Benin City, Nigeria. ${ }^{2}$ Department of Chemistry, College of Arts and Sciences, University of Kentucky, Lexington, USA. ${ }^{3}$ Department of

Microbiology, Faculty of Life Sciences, University of Benin, PMB 1154, Benin City, Nigeria.

Received: 1 February 2020 Accepted: 3 July 2020

Published online: 09 July 2020

\section{References}

1. Oikeh El, Oriakhi K, Omoregie ES. Phenolic content and in vitro antioxidant activities of sweet Orange (Citrus sinensis L.) fruit wastes. Archives of Basic and Applied Medicine. 2014;2(2):119-26.

2. Liu Y, Heying E, Tanumihardjo SA. History, global distribution, and nutritional importance of Citrus fruits. Compr Rev Food Sci Food Saf. 2012;11(6):530-45. 
3. Martínez-Cuenca MR, Primo-Capella A, Forner-Giner MA. Influence of rootstock on Citrus tree growth: effects on photosynthesis and carbohydrate distribution, plant size, yield, fruit quality, and dwarfing genotypes. 2016. InTech.

4. Mandalari G, Bennett RN, Bisignano G, Saija A, Dugo G, et al. Characterization of flavonoids and pectin from bergamot (Citrus bergamia Risso) peel, a major byproduct of essential oil extraction. Journal of Agriculture and Food Chemistry. 2006;54:197-203.

5. Hegazy AE, Ibrahium Ml. Antioxidant activities of Orange Peel extracts. World Appl Sci J. 2012;18(5):684-8.

6. Putnik P, Bursać Kovačević D, Režek Jambrak A, Barba FJ, Cravotto G, et al. Innovative "Green" and Novel Strategies for the Extraction of Bioactive Added Value Compounds from Citrus Wastes-A Review. Molecules (Basel, Switzerland), 2017;22(5), 680.

7. Oikeh El, Oriakhi K, Omoregie ES. Proximate analysis and phytochemical screening of Citrus sinensis fruit wastes. The Bioscientist. 2013;1 (2):164-70.

8. Ekor M. The growing use of herbal medicines: issues relating to adverse reactions and challenges in monitoring safety. Front Pharmacol. 2014;4:177.

9. Yuan $\mathrm{H}, \mathrm{Ma} \mathrm{Q}$, Ye L, Piao G. The traditional medicine and modern medicine from natural products. Molecules. 2016;21(5):559.

10. Onyeagba RA, Ugbogu OC, Okeke CU, Iroakasi O. Studies on the antimicrobial effects of garlic (Allium sativum Linn), ginger (Zingiber officinale roscoe) and lime (Citrus aurantifolia Linn). Afr J Biotechnol. 2004;3(10):552-4.

11. Ayukekbong JA, Ntemgwa M, Atabe AN. The threat of antimicrobial resistance in developing countries: causes and control strategies. Antimicrob Resist Infect Control. 2017:6:47.

12. Aslam B, Wang W, Arshad MI, Khurshid M, Muzammil S, Rasool MH, Nisar MA Alvi RF, Aslam MA, Qamar MU, Salamat MKF, Baloch Z. Antibiotic resistance: a rundown of a global crisis. Infect Drug Resist. 2018;10(11):1645-58.

13. Rahman S, Parvez AK, Islam R, Khan MH. Antibacterial activity of natural spices on multiple drug resistant Escherichia coli isolated from drinking water. Bangladesh Annals of Clinical Microbiology and Antimicrobials. 2011;10:10.

14. Cicco N, Lanorte MT, Paraggio M, Viggiano M, Lattanzio V. A reproducible, rapid and inexpensive Folin-Ciocalteu micro method in determining phenolics of plant methanol extracts. Microchem J. 2009:91:107-10.

15. Ebrahimzadeh MA, Pourmorad F, Bekhradnia AR. Iron chelating activity, phenol and flavonoid content of some medicinal plants from Iran. Afr J Biotechnol. 2008;7(18):3188-92.

16. Polshettiwar SA, Ganjiwale RO, Wadher SJ, Yeole PG. Spectrophotometric estimation of total tannins in some Ayurvedic eye drops. Indian J Pharm Sci. 2007;69:574-6.

17. Hafidh RR, Abdulamir AS, Vern LS, Bakar FA, Abas F, Jahanshiri F, Sekawi Z. Inhibition of growth of highly resistant bacterial and fungal pathogens by a natural product. The Open Microbiology Journal. 2011;5:96-106.

18. Dhiman A, Nanda A, Ahmad S, Narasimhan B. In vitro antimicrobial status of methanolic extract of Citrus sinensis Linn. Fruit peel. Chronicles of Young Scientists. 2012;3:204-8.

19. Dhanavade MJ, Jalkute CB, Ghosh JS, Sonawane KD. Study antimicrobial activity of lemon (Citrus lemon L.) Peel extract. Br J Pharmacol Toxicol. 2011; 2(3):119-22.

20. Gorniak I, Bartoszewski R, Kroliczewski J. Comprehensive review of antimicrobial activities of plant flavonoids. Phytochem Rev. 2019;18:241-72.

21. Nwankwo IU, Onwuakor CE, Aninweze ON. Antibacterial activity of Ethanolic extracts of Citrus sinensis peels on Staphylococcus aureus, Escherichia coli and Pseudomonas aeruginosa isolated from wound infections. International Journal of Advances in Pharmacy, Biology and Chemistry. 2014;3(4):941-7.

22. El-Desoukey RMA, Saleh ASB, Alhowamil HF. The phytochemical and antimicrobial effect of Citrus sinensis (Orange) Peel powder extracts on some animal pathogens as eco-friendly. EC Microbiology. 2018;14(6):312-8.

23. Baba J, Mohammed SB, Ya'aba Y, Umaru Fl. Antibacterial activity of sweet Orange Citrus sinensis on some clinical Bacteria species isolated from wounds. Journal of Family Medicine and Community Health. 2018:5(4):1154.

24. Aboellil AH, Al-Tuwaiji MMY. Effect of some alternative medicine and biological factors on Candida albicans in Saudi Arabia. Journal of Yeast and Fungal Research. 2010;1(6):100-7.

\section{Publisher's Note}

Springer Nature remains neutral with regard to jurisdictional claims in published maps and institutional affiliations.

\section{Submit your manuscript to a SpringerOpen ${ }^{\circ}$ journal and benefit from:}

- Convenient online submission

- Rigorous peer review

- Open access: articles freely available online

- High visibility within the field

- Retaining the copyright to your article

Submit your next manuscript at $\boldsymbol{\nabla}$ springeropen.com 